\title{
مفهوم شرعة ومنهاج ووجهة في القرآن الكريك
}

\section{Dadan Nugraha}

Pondok Pesantren Syamsul 'Ulum

email: dadannugraha60@gmail.com

\section{ملخص البحث}

ههدف هذا البحث إلى معرفة المعاني المعجمية لألفاظ "شرعة ومنهاج ووجهة" وما اشتق منها،

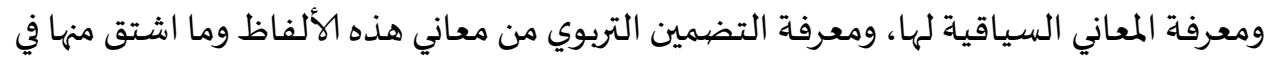

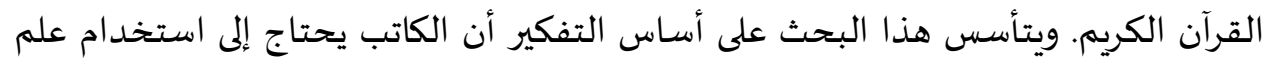

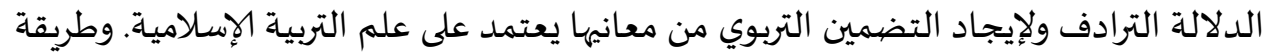

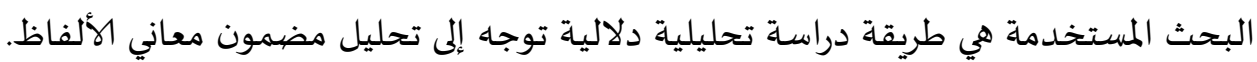

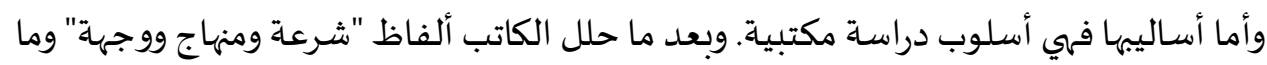

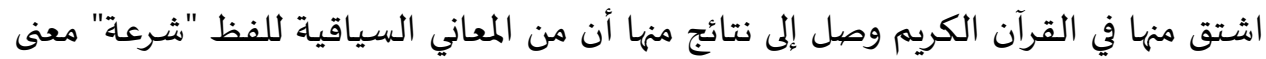

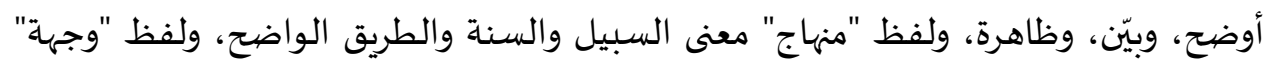

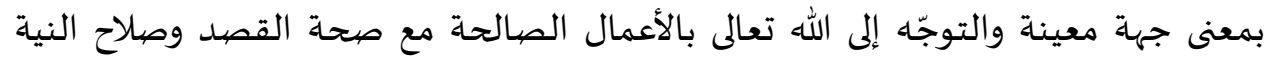
والإخلاص وذي الجاه والمنزلة والكريمة. الكلمات الرئيسية: الدلالة، الطريق، التربية.

\begin{abstract}
ABSTRAK
Penelitian ini bertujuan untuk mengetahui makna leksikal, makna kontekstual dan kandungan nilai pendidikan dari kata "syir'ah, minhaj, wijhah" serta derivasinya di dalam Alquran. Penelitian ini didasarkan pada kerangka berpikir dengan menggunakan ilmu semantik yaitu tarāduf (sinonim) sebagai alat untuk mengetahui makna-makna yang mempunyai implikasi terhadap ilmu pendidikan Islam. Adapun metode penelitian yang digunakan adalah studi analisis semantik dengan mengarah pada analisis makna yang terkandung pada kata tersebut dan teknik pengumpulan data dalam penelitian ini menggunakan teknik studi pustaka. Setelah peneliti menganalisis kata "syir'ah, minhaj, wijhah" serta derivasinya di dalam Alquran, dapat disimpulkan bahwa kata "syir'ah" bermakna "jelas", "nampak"; kata "minhaj" bermakna "jalan yang jelas" dan kata "wijhah" bermakna "menuju Allah SWT. dengan melaksanakan amal saleh serta niat yang ikhlas, dan memiliki kedudukan yang mulia".
\end{abstract}

Kata kunci: Ad-dilālah, Ath-Tharìq, At-Tarbiyah 
Ta’lim al-'Arabiyyah

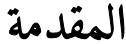

القرآن الحكيم هو آية الله العظهى، ومعجزته الكبرى، وحجته البالغة، ونوره الساطع،

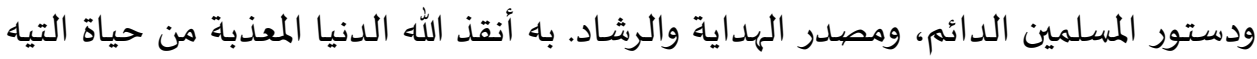

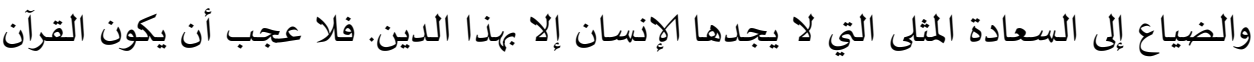

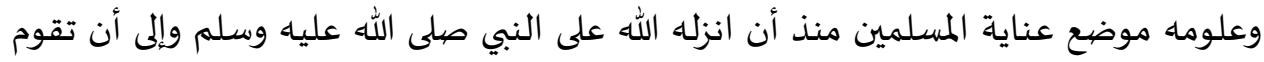

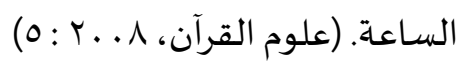

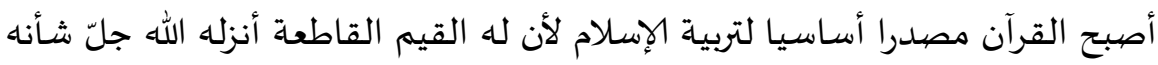

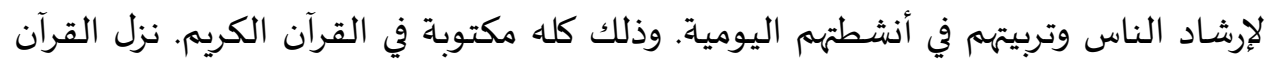

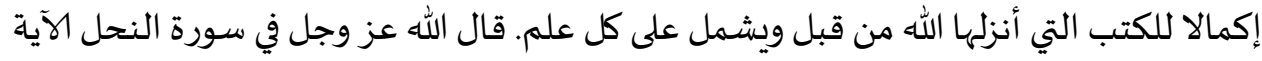

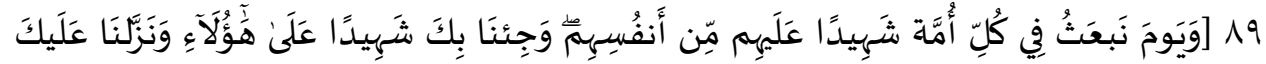

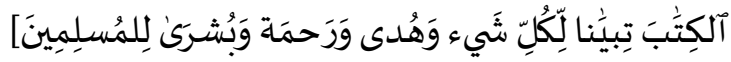

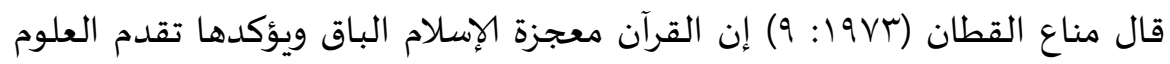

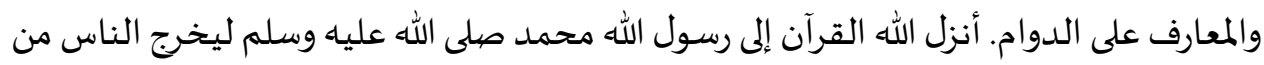

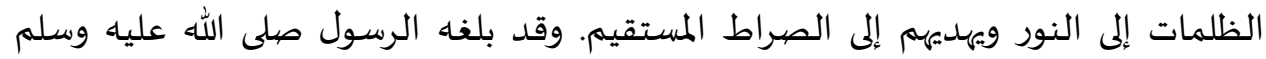
لأصحابه العربيين حتى يقدروا على فهم آيات وهم يستطيعون على سؤال الرسول صلى الله عليه المهيه

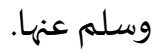

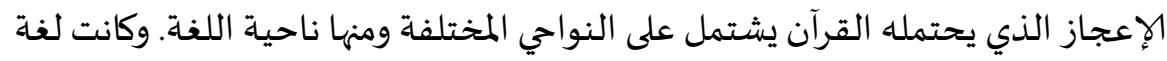

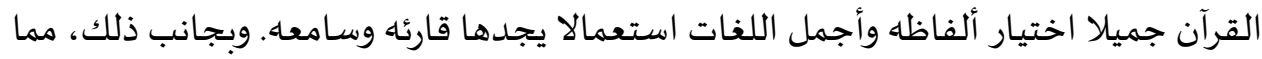

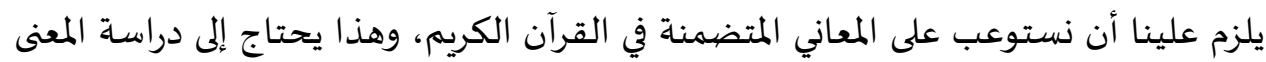

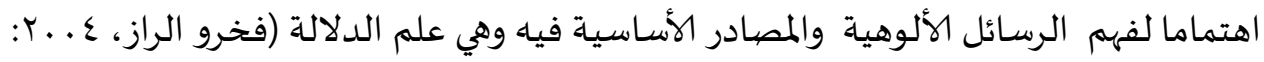

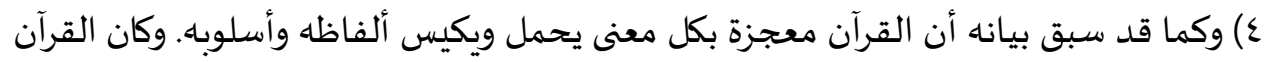

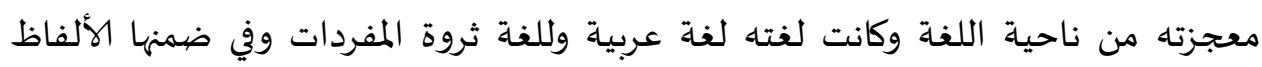

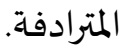

ومن الألفاظ التي يبحث عنها الكاتب في القرآن الكريم هي لفظ "شرعة ومنهاج ووجهة"

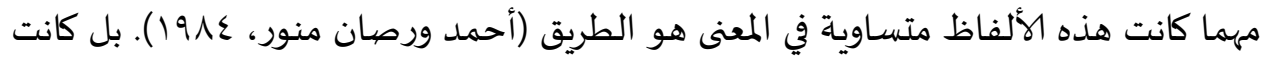

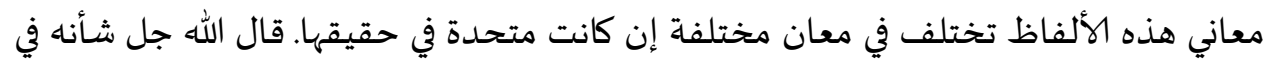

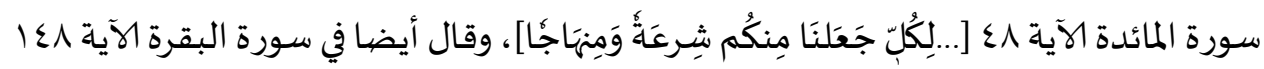




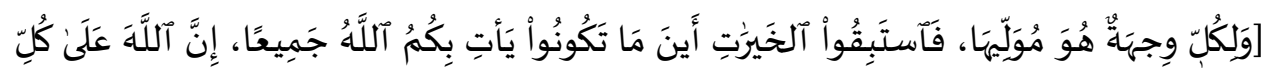

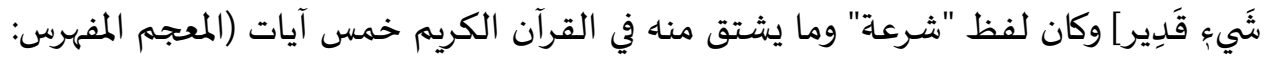

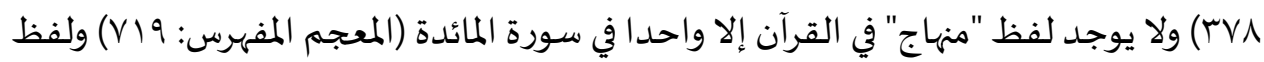

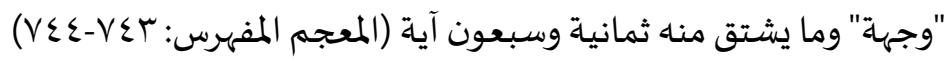

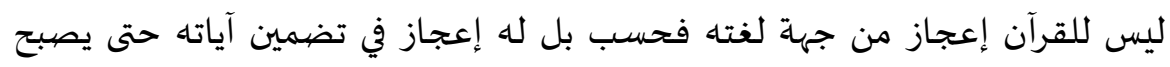

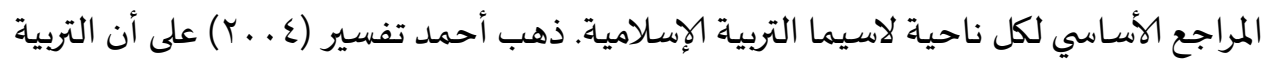

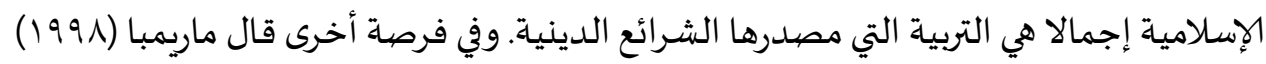
التربية الإسلامية وسيلة للرياضة الجسمية والروحية على أساس شريعة الإسلام (هيري غوناوان، ع ا •r: 9).

وينتج عن ذلك أن التربية الإسلامية لها علاقة وثيقة بشرائع الإسلام. كان القرآن والسنة

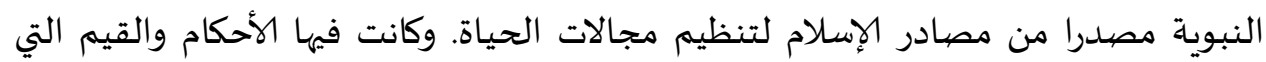

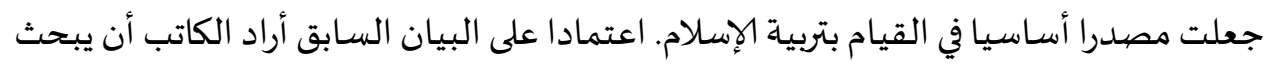

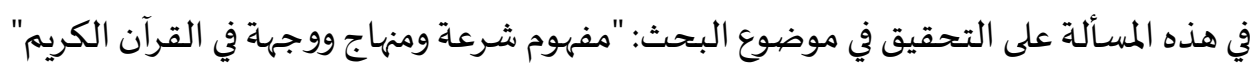

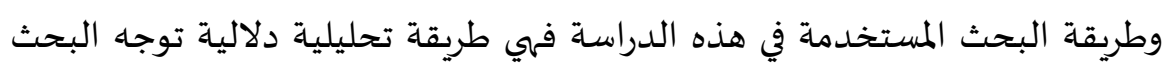
لتحليل معاني الألفاظ، وطريقة موضوعية أي طريقة تستخدم في تفسير آيات القرآن الكريم

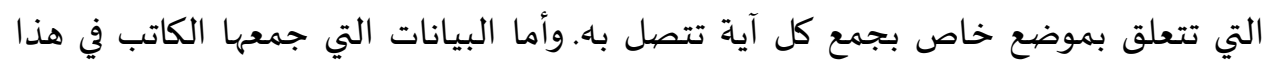
البحث فهي البيانات المكتوبة المأخوذة من مختلف الكتب، مثل كتب التب التفسير والدلالة والمعاجم بهات

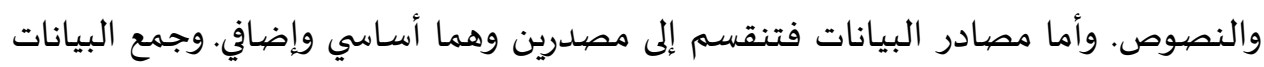

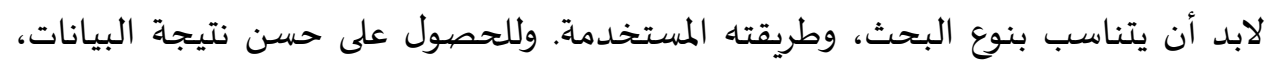

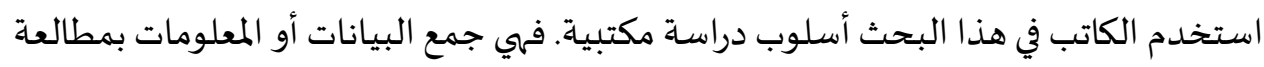

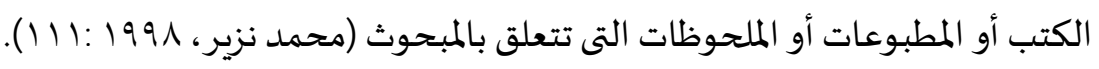

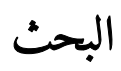

التحليل النظري عن علم الدلالة

القرآن معجزة الإسلام الباق ويؤكدها تقدم العلوم والمعارف على الدوام. أنزل الله القرآن

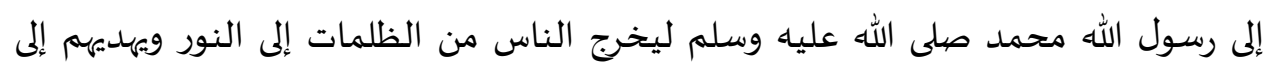

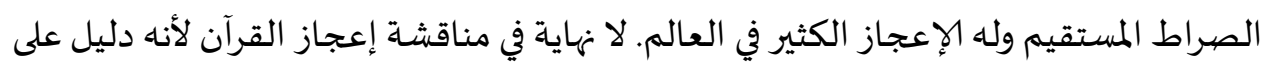

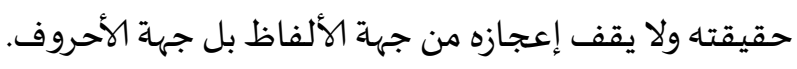


Ta’lim al-'Arabiyyah

حينما ننظر إلى إعجاز القرآن ونهتم باه من ناحية الألفاظ، نجد كلمتين المختلفتين أو أكثر ولكنها متساويان في المعنى ويسمى هذا في علم الدلالة بالترادف. وقال أيميل بديع يعقوب إدها

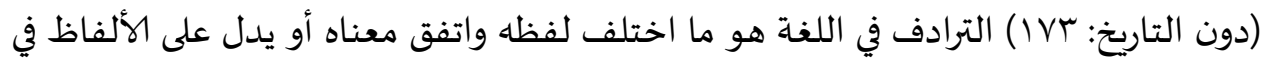
مدلول ومثله لفظ شرعة ومنهاج ووجهة وما اشتق منها. ووجدت هذه كلها في القرآن الكريم بمختلف الصيغةة. وتسمى بترادف لأنها متساوية في المعنى هو الطريق.

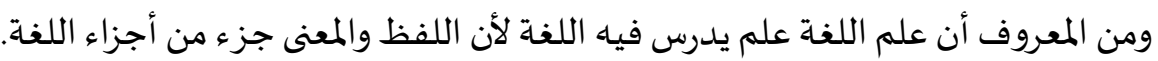

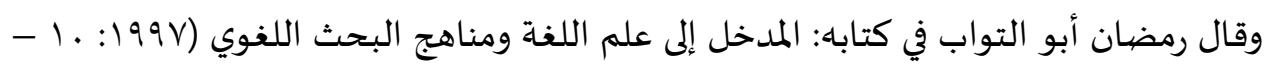
r أن أن علم اللغة يشتمل على العناصر وهي: ا ـ دراسـة الأصيوات التي تتألف منها اللغة، ويتناول ذلك تشريح الجهاز الصيوتي لدي الإنسان، ومعرفة إمكانات النطق المختلفة الكامنة ووصف أماكن النطق ومخارج الأصيوات في هذا الجهاز، وتقسيم الأصيوات الإنسانية إلى مجموعات، تظهر في كل مجموعة منها خصائص معينة، ودراسة المقاطع الصوتية، والنبر والتنغيم في الكلام،

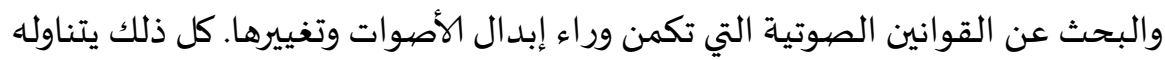
فرع خاص من فروع اللغة وهو علم الأصوات. r ـ دراسـة البنية، أو البحث في القواعد المتصلة بالصيغ، واشتقاق الكلمات وتصريفها، وتغيير أبنية الألفاظ للدلالة على المعاني المختلفة وهو ما يدرس عند العرب باسم بعلم الصرف. ب. دراسـة نظام الجملة، من حيث ترتيب أجزائها وأثر كل جزء منها في الآخر وعلاقة هذه

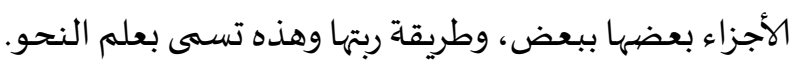
ع ـ دراسة دلالة الألفاظ أو معاني المفردات والعلاقة بين هذه الدلالات والمعاني المختلفة والحقيقي منها والمجازي والتطور الدلالي وعوامله ونتائجهاه ونشوء الترادف والإشتراك اللفظي والأضيداد وغير ذلك. وهذه تسمى بعلم الدلالة. 0 ـ ـ البحث في نشأة اللغة الإنسانية. 7 . الاقة اللغة بالمجتمع الإنساني والنفس البشرية. V . البحث في حياة اللغة. 
وقال محمد علي الخولي (9191: 11) إن علم اللغة هو العلم الذي يدرس اللغة وهو ينقسم إلى فرعين:

ا ـ علم اللغة النظري. ويشمل هذا الفرع عدة علوم منها علم الأصوات وعلم الفونيمات

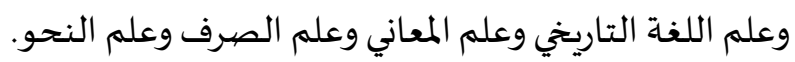
r . علم اللغة التطبيقي. ويشمل هذا الفرع عدة علوم منها تدريس اللغات الأجنبية والترجمة وعلم اللغة النفسي وعلم اللغة الاجتماعي.

وفي خصائص أن اللفظ والمعنى يبحثان في علم المعاني هما من الفروع في علم اللغة

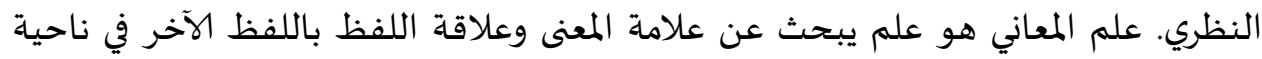
المعنى. بعض علماء اللغة يذكروها بعلم الدلالة.

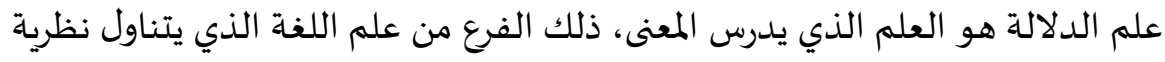

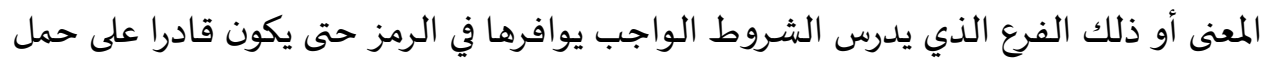
المعنى (أحمد مختار عمر: 199 19 : 11) ).

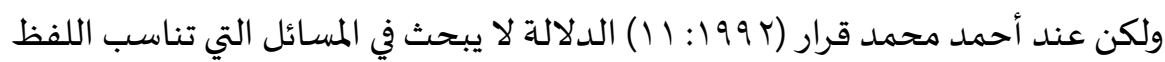

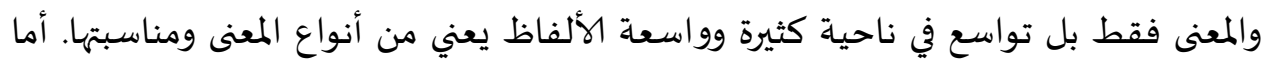

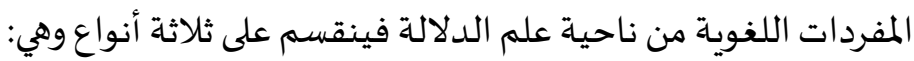
ا ـ المتباين، وهو أن يدل اللفظ الواحد على معنى واحد وهو أكثر اللغة.

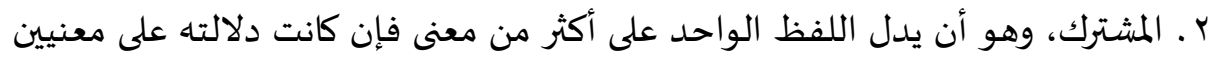

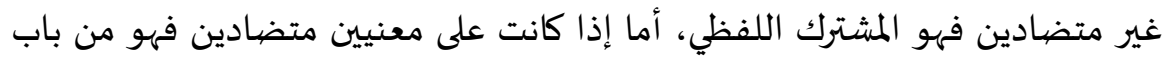
الأضيداد. r. المترادف، وهو أن يدل أكثر من لفظ على معنى واحد. والحاصل أن اللفظ في اللغة العربية نجده كثيرا بوجود العلاقة المعنوية أو أنواع دلالة

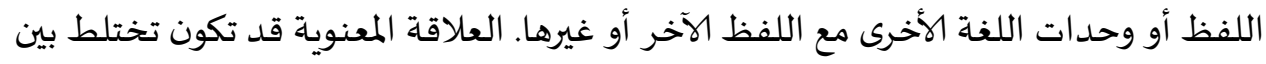
الأنواع الثلاثة السابقة. وقد اختلف اللغويون العرب القدماء اختلافا واسعا في إثبات وإنكار الترادف في اللغة

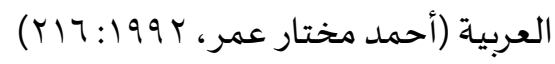

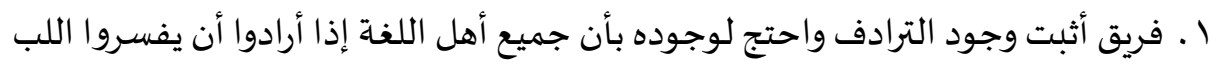

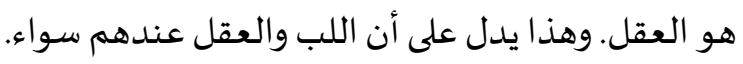


Ta’lim al-'Arabiyyah

قال ابن فارس: لو كان لكل لفظ معنى غير الأخرى لما أمكن أن يعبر عن شيء بغير عبارة، وذلك لا نقول في لا ريب فياء: لا شك فياه فلو كان الريب غير الشك لكانت العبارة خطأ. r ـ فريق آخر كان ينكر الترادف، منهم أبو علي الفارسي يقول: لا أحفظ للسيف إلا اسما واحدا وهو السيف وحين سئل: فأين المهند والصارم وكذلك...وكذلك...قال: هذه ئه الصفات.

ويقول أصحاب الرأي ردا على مخالفيهه: نحن نقول إن في "قعد" معنى ليس فيه "جلس". ألا ترى أنا نقول: قام ثم قعد، وأخذه المقيم والمقعد، وقعدت المرأة عن الحيض. ونقول لناس من الخوارج: قعد، ثم نقول: كان مضطجعا فجلس، فيكون العقود عن قيام والجلوس عن حالة هي دون الجلوس، لأن الجلوس المرتفع والجلوس ارتفاع عما هو دوناء. ومما سبق بيانه، استنبط الكاتب أن المترادف هو الألفاظ لها معنى على سواء أو معنى

يميز كثير من المحدثين بين أنواع مختلفة من الترادف وأشباهاه على النحو التالي (أحمد

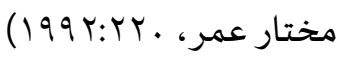
الت الترادف الكامل

الترادف الكامل (Perpect Synonymy/ Complete Synonymy) أو التماثل (Sameness)، وذلك حين يتطابق اللفظان تمام المطابقة ولا يشعر أبناء اللغة بأي فرق بينهما، ولذا يبادلون بحريّة بينهما في كل السياقات. وسنعرض فيما بعد رأي المحدثين بهـين حول وجود أو عدم وجود هذا النوع في اللغة الواحدة. r ـ شببه الترادف

شبـ الترادف (Near Synonymy/ Quasi Synonymy/ Less-Full Synonymy) أو التشابه (Contiguity) أو التقارب التداخل (Oveness) أو (Overlapping) وذلك حين

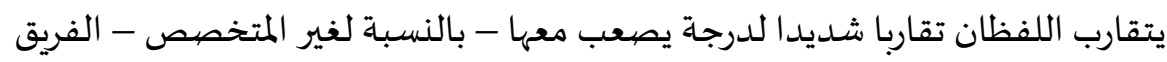
بينهما، ولذا يستعملهما الكثيرون دون تحفظ مع إغفال هذا الفرق، مثل: عام - سنة حول، وثلاثتها قد وردت في مستوى واحد من اللغة، وهو القرآن الكريه.

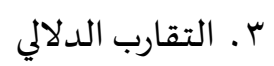

التقارب الدلالي (Semantic Relation) ويتحقق ذلك حين تتقارب المعاني، لكن يختلف كل لفظ عن الآخر بملمح هام واحد على الأقل. ويمكن التمثيل لهذا النوع 
بكلمات كل حقل دلالي على حدة، وبخاصة حين نضيق مجال الحقل ونقصره على أعداد

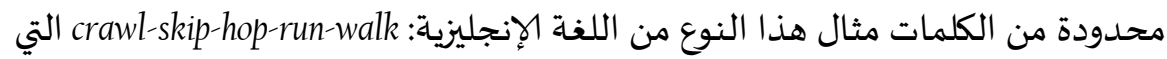

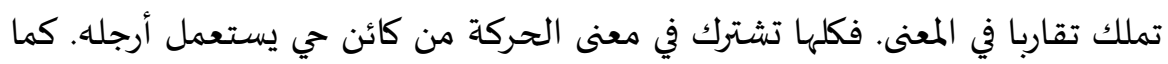
يمكن التمثيل له من العربية بكلمتي "حلم ورؤيا" وهما من الكلمات القرآنياة.

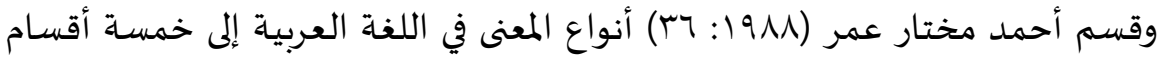

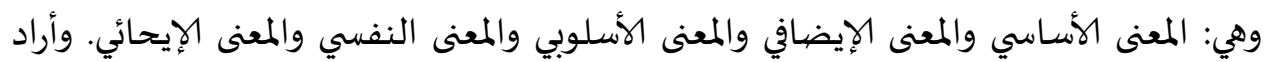
الكاتب أن يبحث معنيين منها في هذه الرسالة وهما: المعنى الأساسي والمعنى السياقي.

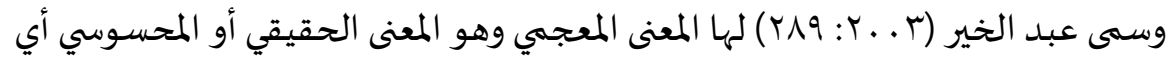
يدرك بالحسي أو الحواس ويكون في المعاجم الأساسية.

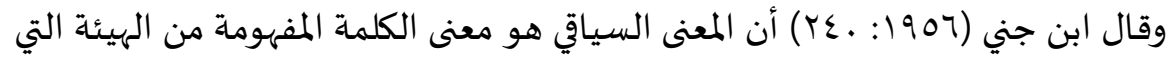

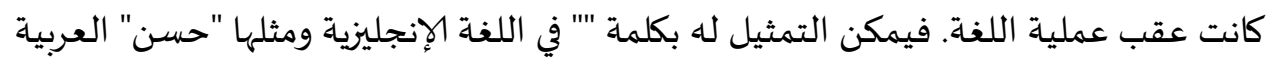

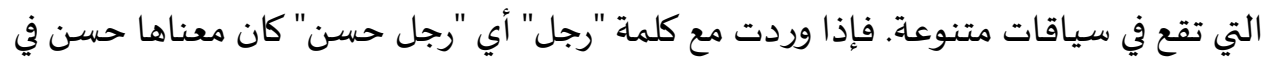

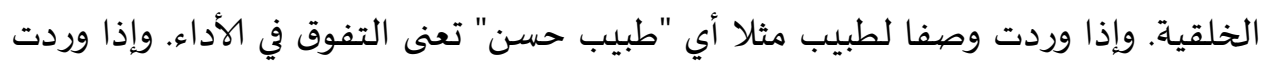
وصفا للمقادير كان معناها الصفاء والنقاوة.

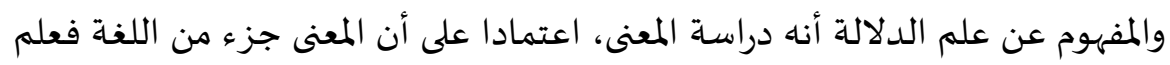

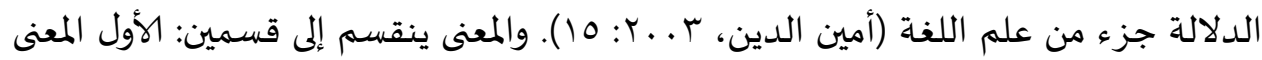

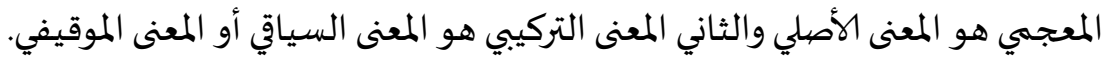

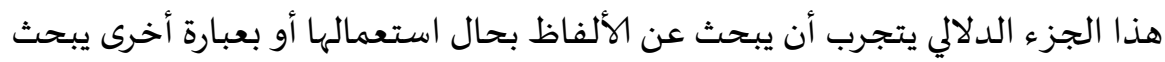

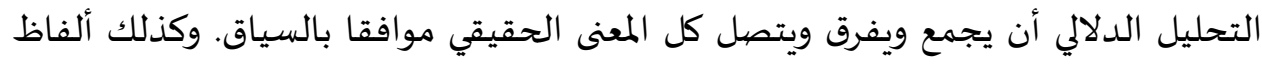

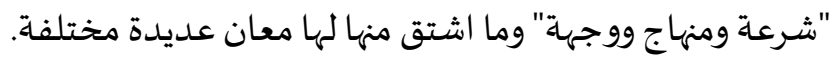

\section{مفهوم شرعة ومنهج ووجهة في القرآن الكريم}

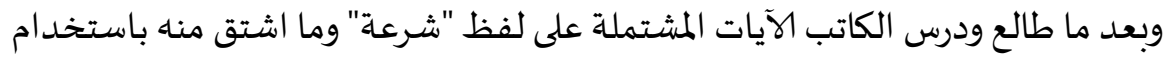

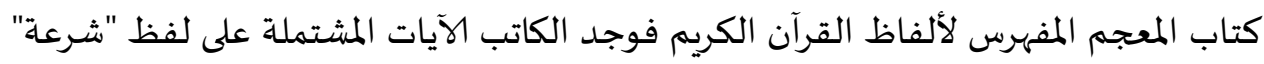

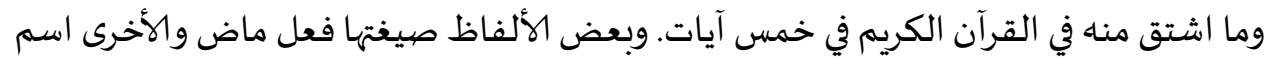

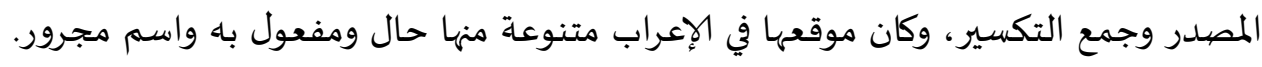

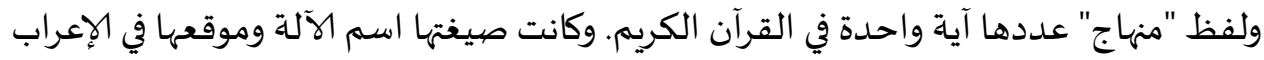

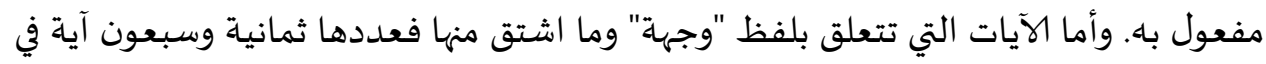


Ta'lim al-'Arabiyyah

القرآن الكريم. وثلاث آية صيغتها فعل ماض وفعل مضارع والباقية صيغتها اسم المصيدر وجمع التكسير وصيغة مبالغة، وموقعها في الإعراب متنوعة منها فاعل ومفعول باه ومضياف إليه و

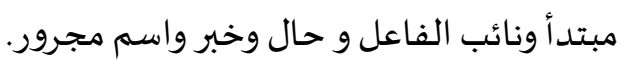
وبعد ما عرفنا الآيات المشتملة على الألفاظ "شرعة ومنهج ووجهرة واتهات في القرآن الكريم فنحلل المعاني المعجمية والسياقية لكل ألفاظ. والمعنى المعجمي للفظ شرعة هو الشرع نهح

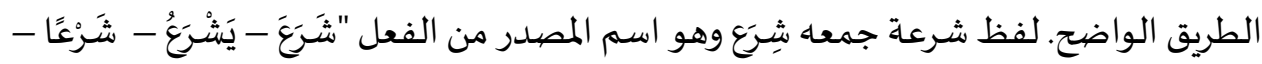

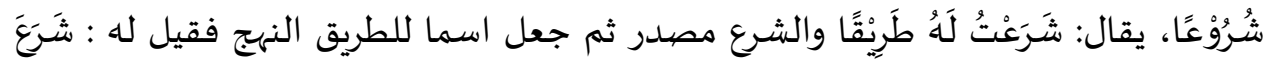

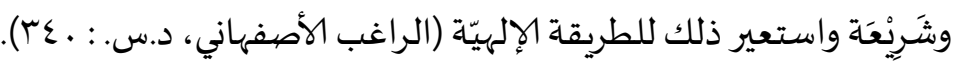
ولفظ الشريعة والشراع والمشرعة معناها المواضع التي ينحدر إلى الماء منها، قال الليث وبها سمي ما شرع الله للعباد شريعة من الصوم والصلاة والحج والزكاة وغيره. والشريعة موضع على شاطئ البحر تشرع فيه الدواب. والشريعة والشرعة ما سنّ الله من الدين وأمر به. والمعاني للفظ "شرعة" وما يشتق منه كما كتب ابن منظور في كتابه لسان العرب في ما يلي : ( ) قال

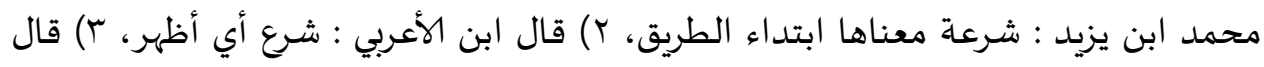

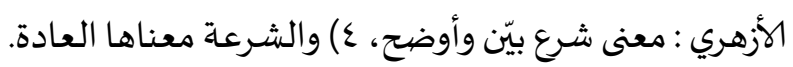
ولفظ "منهاج" جمعهه مناهج وهو اسم الآلة من الفعل نَهَجَج - يَنْهَجُ - نَهْجًا معناه النهج

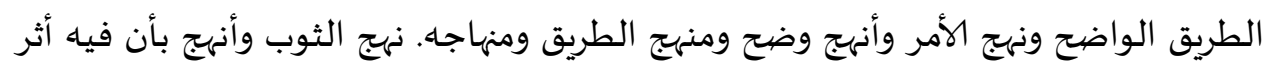
البلى وقد أنهجه البلى. (الراغب الأصفهاني، د.س. : 707). لفظ "منهاج" معناه الطريق الواضح

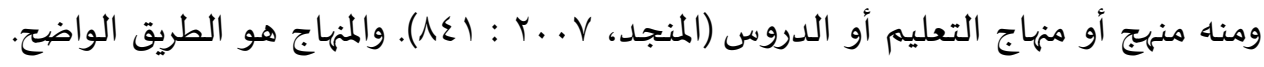

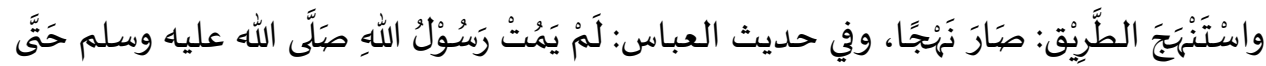

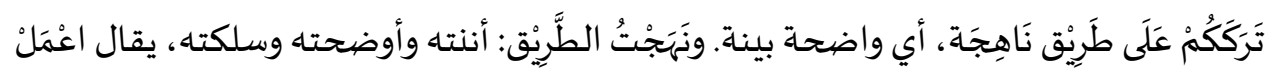

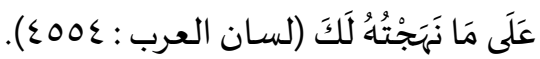

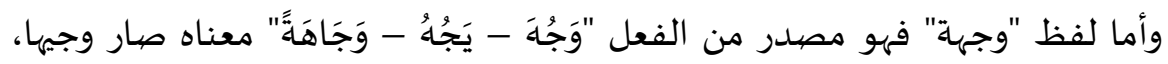

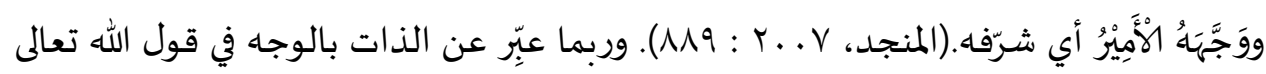

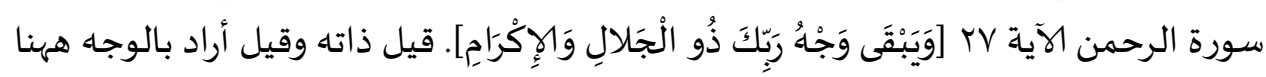

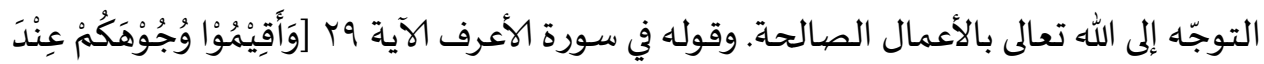

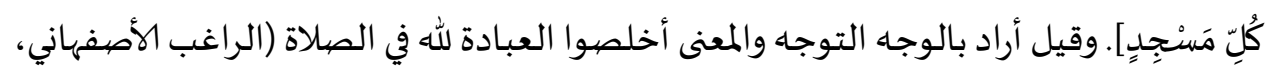
د.س.: (77). 
والوجهة معناها الموضع الذي تتوجه إليه وتقصده وضل وجهة أمره أي قصده. قال أبو

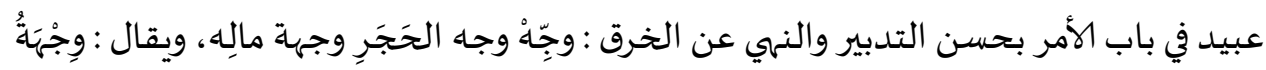

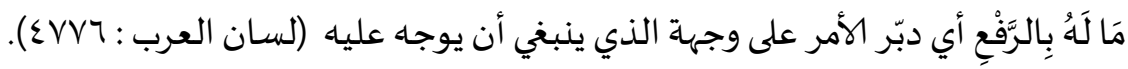

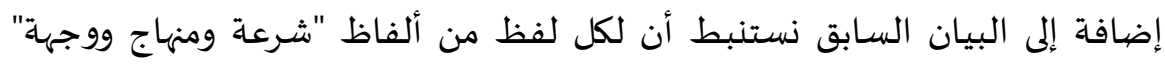

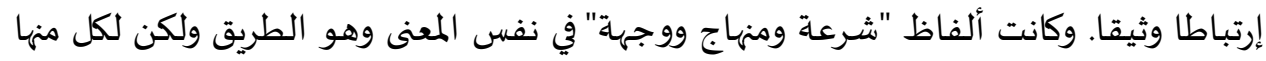

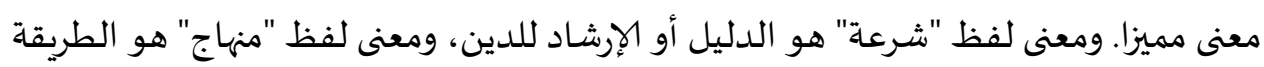
ومعنى لفظ "وجهاة" هو الهدف الموجها.

ولفظ "شرعة" من حيث المعاني السياقية فوجد الكاتب أن معنى شرعة سياقيا كما

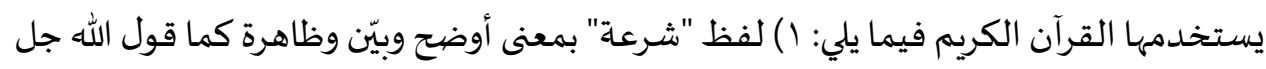

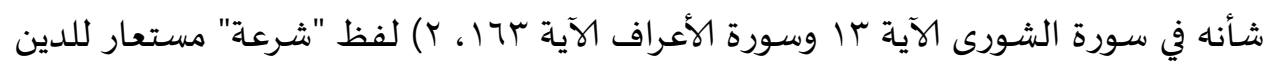

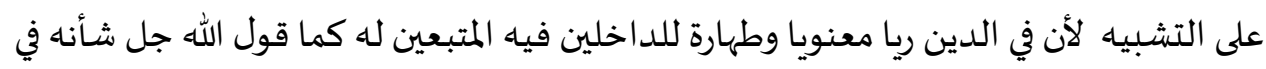

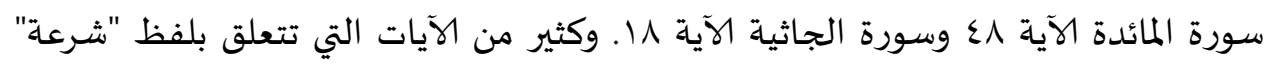

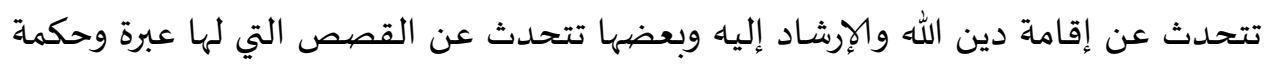
كبيرة.

ولفظ "منهاج" من حيث المعاني السياقية كما يستخدمها القرآن الكريم فيما يلي: () )

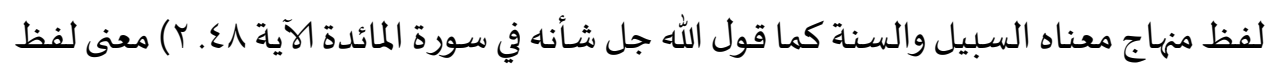

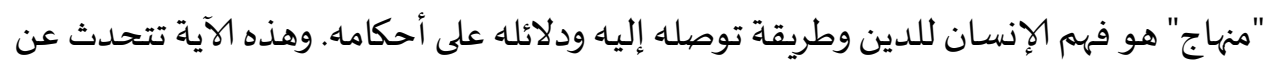

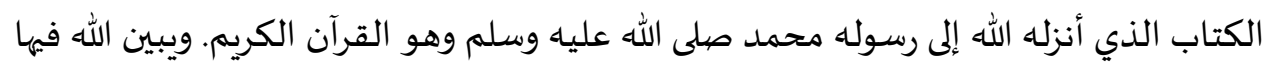
أن لكل أمة الإرشاد للدين والهدى من الله تعالى.

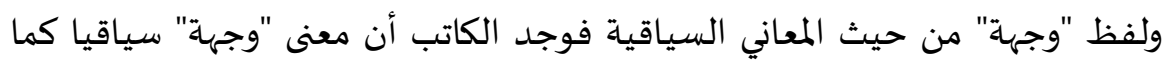

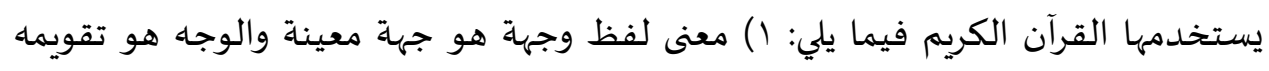

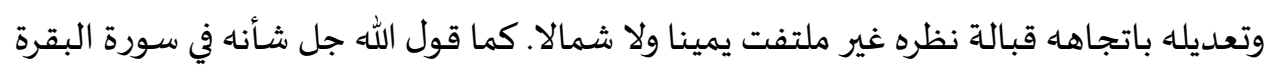

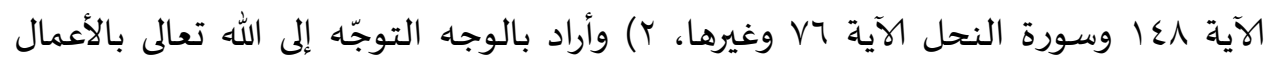

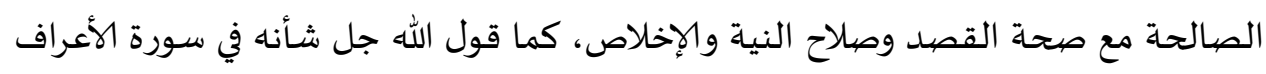

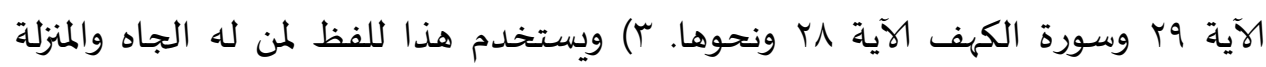

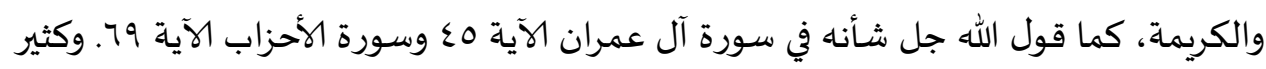

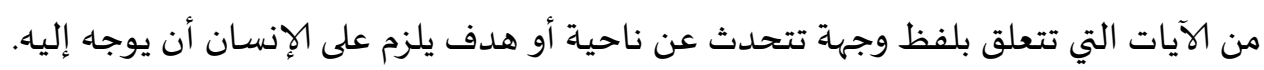

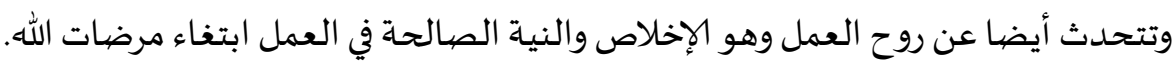




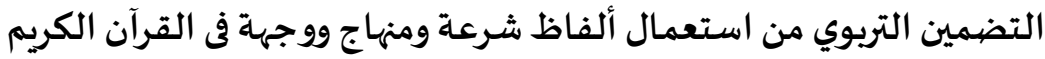

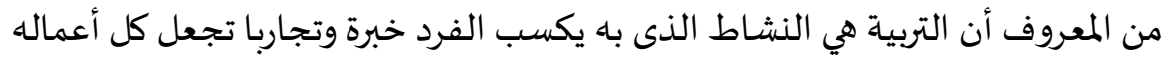

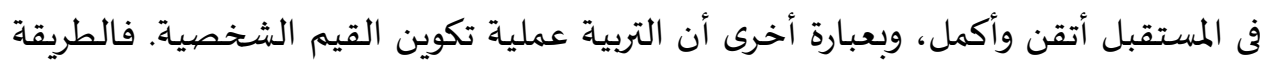
التربية هو النظام أو الأسلوب الذى يسير عليه الممبي في تربية النشئ للحصيول على أغرى أغراضيه

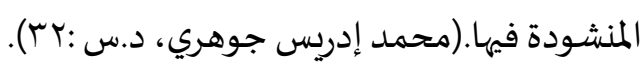

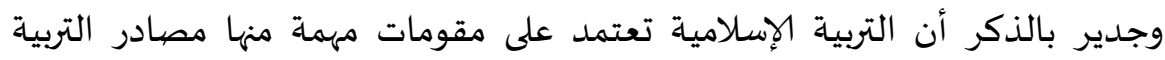

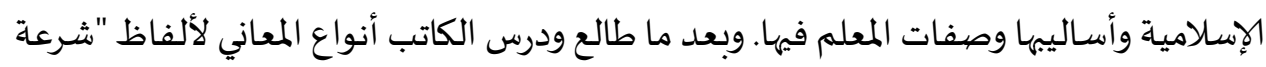

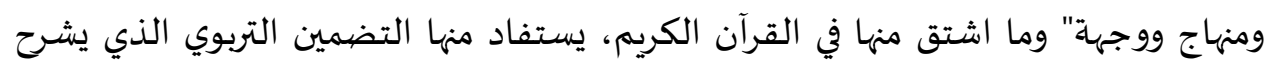
موجزا فيما يلي: ومنهاج وتها

$$
\text { ا. مصادر التربية الإسلامية }
$$

فالتربية الإسلامية ضرورة حتمية لتحقيق الإسلام كما أراد الله أن يتحقق وهي بهذا المعنى الإسية

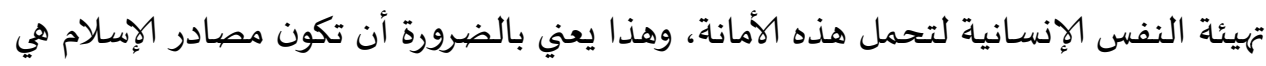

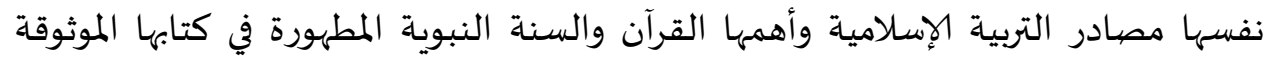

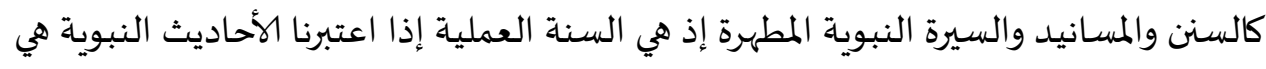
السنة النظرية (علي عبد الحليم محمود، 1990: 190 ه).

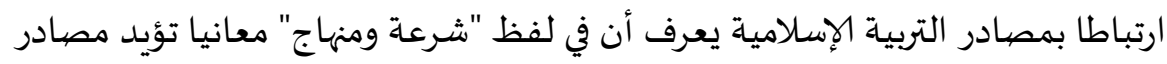

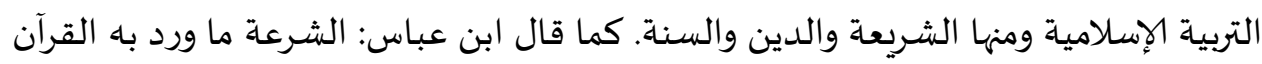
والمنهاج ما ورد باه السنة (الراغب الأصفهاني، د.س. : . عץ). r. أساليب التربية الإسلامية

مما يلزم على المدرس أن يستخدم أساليب الواضحة والبينة المالينة في التربية الإسلامية

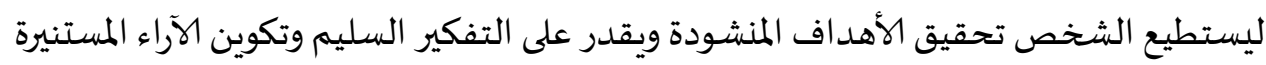

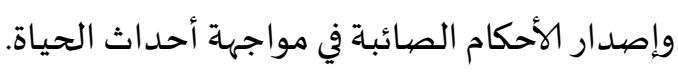

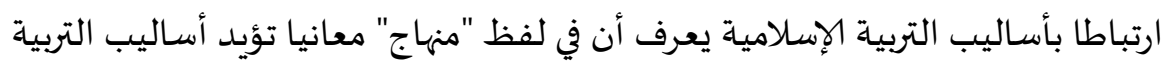

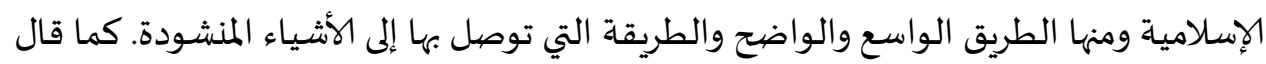

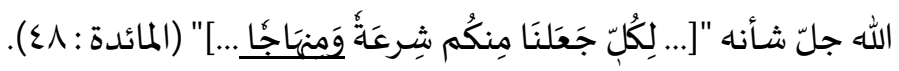




$$
\text { r. - nمفات المعلم }
$$

المعلم هو القائد التربوي الذي يتصدر لعملية توصيل الخبرات والمعلومات التربوية

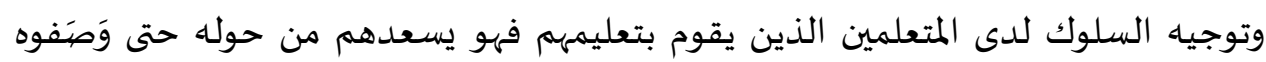

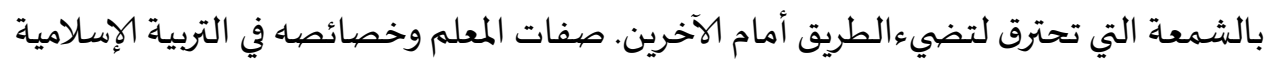

أ- الطاعة

الطاعة من صفات المعلم على وجه عام بمعنى التقوى. والتقوى هو الخوف

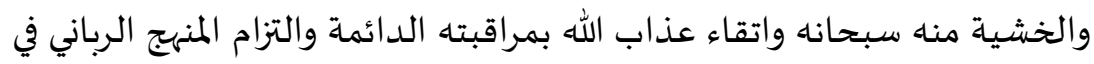

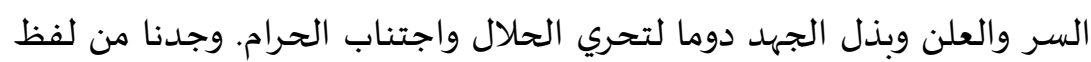

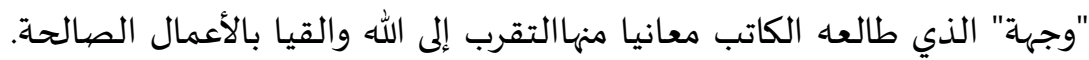

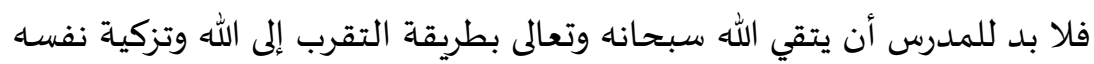

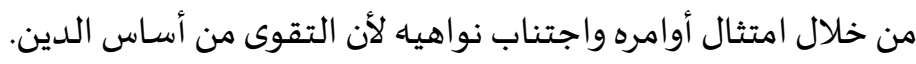

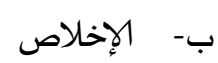

الإخلاص هو فضيلة من الفضائل وخلق من الأخلاق الحسنة الحميدة، والتي

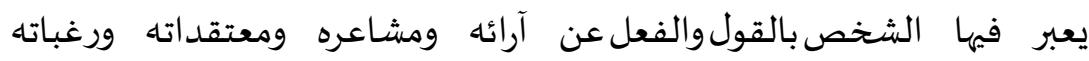

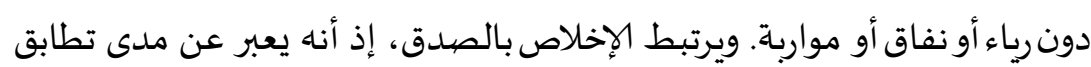
القول مع الفعل. أمر الله -تعالى- بالتحلّي بالأخلاق الحسنة، كما بعث رسوله محمد -صلّى الله

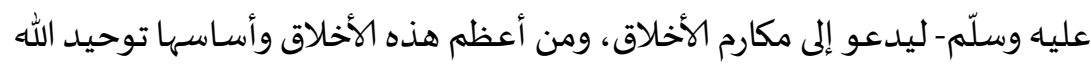

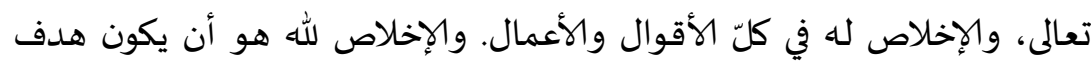

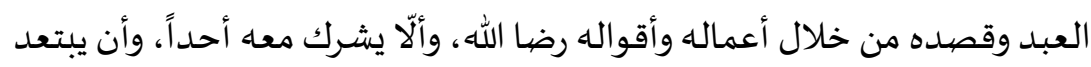

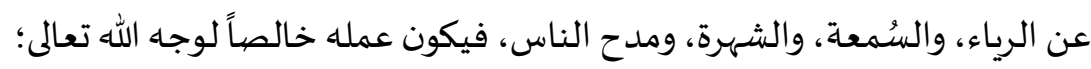

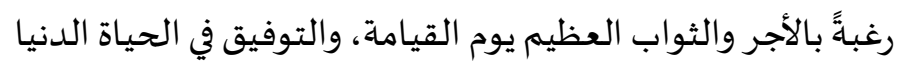

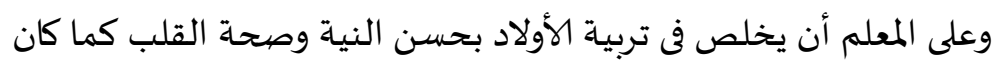
لفظ "وجهة" بمعنى الإخلاص. الإخلاص في التعليم بأن يعمل المعلم لإرضاء الله

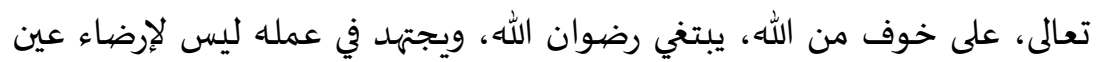

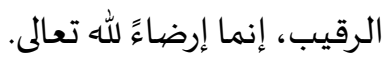


الأخلاق مصطلح يطلق على الهيئة والحالة الراسخة في النفس، التي ينبي

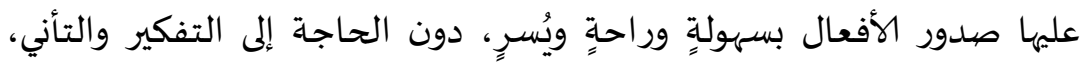

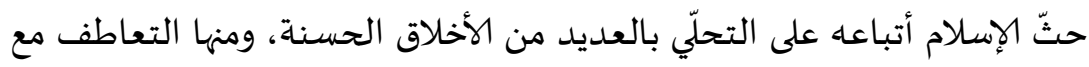

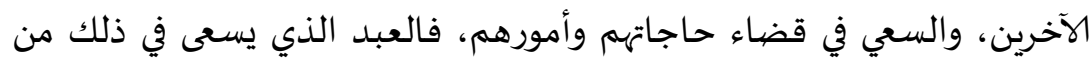

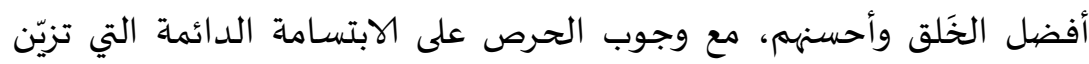

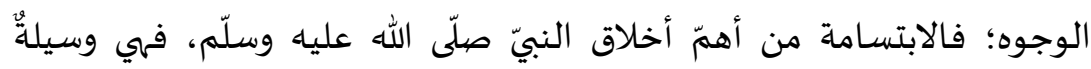

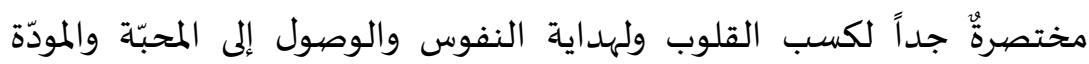
والسكينة والطمأنينة،

ومما يلزم على المعلم أن يستحق الأخلاق الكريمة والهيبة في حياته، لأنها

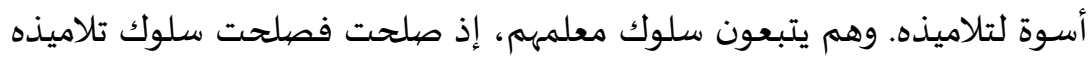

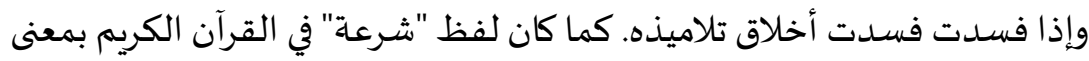

$$
\text { ذو كريمة ومنزلة عالية عند ربه. }
$$

\section{النتيجة}

وبعد ما حلل الكاتب عن معاني لفظ "شرعة ومنهاج ووجهة" وما اشتق منه في القرآن

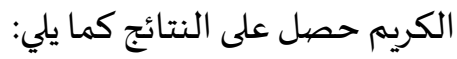

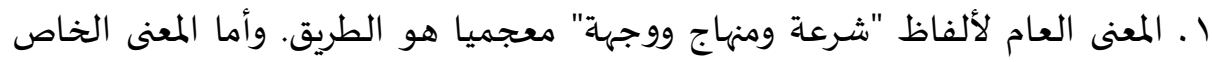

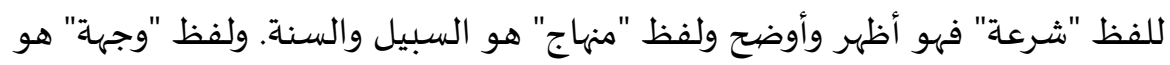
الإخلاص والتوجه. r ـ وأما المعاني السياقية للفظ "شرعة ومنهاج ووجهة" وما اشتق منه في القرآن الكريم فهي:

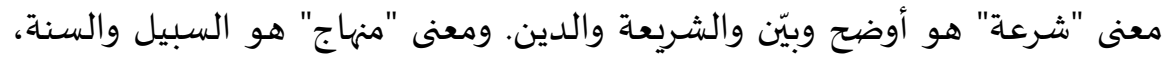

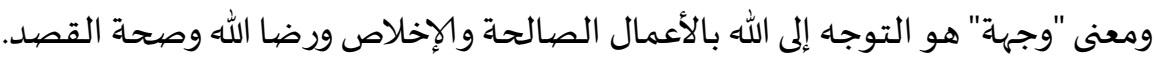

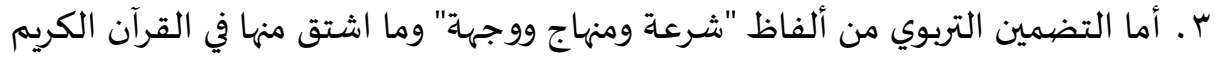

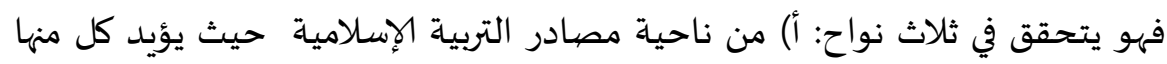

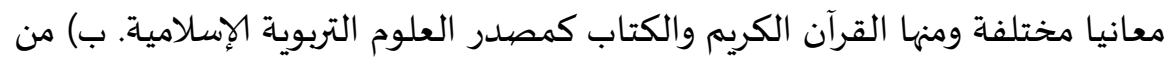

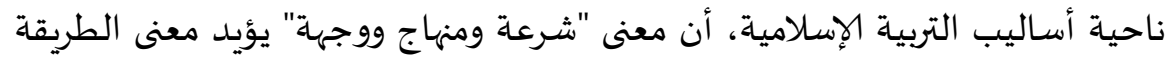


الألفاظ أهمية الطاعة والبينة. ج) ومن ناحية صفات المعلم في التربية الإسلامية حيث يؤيد معنى هذه

المراجع

الحسين، أبي القاسم بن محمد المعروف بالراغب الأصفهاني. د.س. المفردات في غريب القرآن. مكتبة نزار مصطفى الباز.

ذنون النعمة ، إبراهيم نعمة الله. ^ . . r. علوم القرآن.

الرازي، فخر الدين. . 199. مفاتيح الغيب. بيروت: دار الفكر.

عبد الباقي، محمد فؤاد ـ ع£ 19. المعجم المفهرس لألفاظ القرآن الكريم. القاهرة: دار الديث.

القطان، مناع خاليل . I9VT ـ مباحث في علوم القرآن. بيروت: منشورة العصر الحديث.

المراغي، أحمد بن مصطفى. 197 ـ تفسير المراغي. مصر: شركة مكتبة ومطبعة مصطفى البابى

الحلبي .

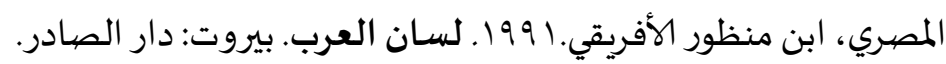

اليسوعي، الأب لويس معلوف. 19rV.المنجد معجم عربي مدرسي مع رسوم. بيروت:

الكاسوليكية.

Alquran Al-Karim. 2016. Alquran Tajwid dan Terjemah (Alquran Tafsir Bil Hadis). Bandung: Cordoba.

Aminuddin. 2002. Semantik Pengantar Studi tentang Makna. Sinar Baru Bandung: Algesindo.

Chaer, Abdul. 2002. Pengantar Semantik Bahasa Indonesia. Jakarta: Rineka Cipta.

Gunawan, Heri. 2014. Pendidikan Islam Kajian Teoritis dan Pemikiran Tokoh. Bandung: Rosda.

Munawwir, Ahmad Warshon. 2002. Almunawwir Kamus Arab-Indonesia. Yogyakarta: Pustaka Progresif.

Quraish Shihab, Muhammad. 1998. Mukjizat Al-Quran. Bandung: Mizan. 